\title{
Partial Caries Removal in Deep Lesions: 19-30 months follow-up study
} Remoção Parcial de Dentina Cariada em Lesões Profundas: estudo de 19-30 meses de acompanhamento

Marisa Maltz ${ }^{1}$, Maurício dos Santos Moura ${ }^{2}$, Juliana Jobim Jardim³ ${ }^{3}$ Cyntia Marques ${ }^{4}$, Lilian Marly De Paula ${ }^{5}$, Heliana Dantas Mestrinho ${ }^{6}$

\section{Resumo}

O objetivo deste ensaio clínico controlado randomizado multicêntrico foi avaliar a efetividade da remoção parcial de dentina cariada seguida de restauração em única sessão (RPDC) em lesões de cárie profundas no Brasil (Porto Alegre e Brasília) após dois anos de acompanhamento. Critérios de inclusão: pacientes com $\geq$ seis anos de idade apresentando molares permanentes com lesões profundas primárias, ausência de alteração periapical, sensibilidade pulpar, ausência de dor espontânea e sensibilidade à percussão negativa. Os indivíduos foram randomicamente atribuídos ao grupo teste - RPDC, ou grupo controle - tratamento expectante (TE). O TE consistiu na remoção parcial de dentina cariada, capeamento pulpar indireto com cimento de hidróxido de cálcio, restauração provisória com cimento de óxido de zinco e eugenol, reabertura da cavidade após 60 dias, remoção da dentina cariada remanescente amolecida e restauração. Cada grupo foi dividido de acordo com o material restaurador: amálgama ou resina. Avaliações clínicas e radiográficas foram realizadas anualmente. Os desfechos considerados foram sensibilidade pulpar ao teste frio e ausência de alteração periapical. Foram executados 299 tratamentos, 153 RPDC e 146 TE. Não houve diferença entre os grupos em relação às características basais. Após dois anos de acompanhamento, foram avaliadas 181 restaurações e a taxa de sobrevivência dos tratamentos RPDC e TE foram 95,45\% e $80,85 \%$, respectivamente $(p=0,001)$. Razões dos insucessos: pulpites, osteíte, hiperemia, necroses, extração e fratura da restauração. Nenhuma variável foi significativamente associada ao desfecho. A partir destes resultados, é possível concluir que a RPDC é um tratamento mais efetivo que o TE. (Número de registro no www.clinicaltrials.gov NCT00887952)

Palavras-chave: Cárie dental; Dentina; Restauração dental; Amálgama de prata; Resina composta; Análises de sobrevivência.

\section{Abstract}

The aim of this multicenter randomized controlled clinical trial was to evaluate the effectiveness of partial caries removal followed by restoration in a single session (PDR) for deep caries lesions in Brazil (Porto Alegre and Brasilia) after 2-year follow-up. Inclusion criteria: patients with $\geq$ six years old presenting permanent molars with primary deep lesion, absence of periapical alterations, pulp sensitivity, absence of spontaneous pain and negative percussion test. The subjects were randomly assigned to test group - PDR, or control group - stepwise excavation (SW). SW consisted of partial removal of carious dentine, indirect pulp capping with calcium hydroxide cement, temporary filling, cavity re-opening after 60 days, removal of the remaining soft carious dentine and filling. Each group was divided according to the filling material: amalgam or resin. Clinical and radiographic evaluations were performed in annual basis. The outcomes were considered as pulp sensibility to cold test and absence of periapical alterations. There were performed 299 treatments, 153 PDR and $146 \mathrm{SW}$. There were no differences between the groups regarding baseline characteristics. After 2 years of follow-up, 204 restorations were evaluated and the therapy survival rates of PDR and SW were $95.45 \%$ and $80.85 \%$, respectively $(p=0.001)$. Reasons for failure: pulpitis, osteitis, hyperemia, necrosis, extraction and restoration fracture.. None variable was significantly associated with the outcome. From these results, it is possible to conclude that the PDR is a more successful treatment than SW. (Registration number at www.clinicaltrials.gov NCT00887952).

Keywords: Dental caries; Dentine; Dental restoration; Silver amalgam; Resin composite; Survival analysis.

${ }^{1}$ DDS, MS, PhD - Dr. Marisa Maltz is a professor in the Department of Social and Preventive Dentistry, Faculty of Odontology, Federal University of Rio Grande do Sul, Porto Alegre, Rio Grande do Sul, Brazil

${ }^{2}$ DDS - Dr. Maurício dos Santos Moura is a PhD student in the Department of Social and Preventive Dentistry, Faculty of Odontology, Federal University of Rio Grande do Sul, Porto Alegre, Rio Grande do Sul, Brazil

${ }^{3}$ DDS, MS, PhD - Dr. Juliana Jobim Jardim is an associate professor in the Department of Social and Preventive Dentistry, Faculty of Odontology, Federal University of Rio Grande do Sul, Porto Alegre, Rio Grande do Sul, Brazil

${ }^{4}$ DDS - Dr. Cyntia Marques is a post-graduate student (Master's Degree) in the Department of Odontology, Faculty of Health Sciences, University of Brasilia, Brasília, Distrito Federal, Brazil

${ }^{5}$ DDS, MS, PhD - Dr. Lilian Marly De Paula is an associate professor in the Department of Odontology, Faculty of Health Sciences, University of Brasília, Brasília, Distrito Federal, Brazil

${ }^{6}$ DDS, MS, PhD - Dr. Heliana Dantas Mestrinho is an associate professor in the Department of Odontology, Faculty of Health Sciences, University of Brasília Brasília, Distrito Federal, Brazil

Correspondência: Marisa Maltz

Faculdade de Odontologia - UFRGS

Departamento de Odontologia Preventiva e Social

Endereço: R. Ramiro Barcelos, 2492 - CEP 90035-003

Porto Alegre - RS, Brazil

Fone:+ $55513308-5193$

Fax $+55513308-5247$

E-mail: marisa.maltz@gmail.com

Data de Submissão: 21/09/2010

Data de Aceite: 15/09/2011

\section{Introduction}

The conventional treatment of deep caries lesions involves complete removal of carious dentine followed by tooth restoration. In this technique, there is a potential risk of iatrogenic pulp exposure making the course of the treatment less predictable. Alternative approaches have been proposed to preserve pulp sensibility, such as indirect pulp capping (KING; CRAWFORD; LINDAHL, 1965) and stepwise excavation (MAGNUSSON; SUNDELL, 1977). This latter method consists in the removal of decayed tissue in two steps, in which a layer of soft and humid dentine is left over the cavity floor and the tooth is temporarily filled at the first appointment. After variable time intervals ( 60 days -6 months), the residual carious dentine is removed before the placement of the definitive restoration. The aim of this procedure is to allow the occurrence of physiological reactions in the pulp-dentine complex represented by dentine sclerosis and tertiary dentine formation (KING; CRAWFORD; LINDAHL, 1965; MASSLER, 1978), ensuring protection to pulp tissue on the re-entry. Some studies had presented favorable results for this treatment (LEKSELL et al., 1996; BJØRNDAL; THYLSTRUP, 1998). However, disadvantages 
related to the need of reopening for further excavation have been described: the risk of pulp exposure during re-entering the cavity, the failure of the temporary filling leading to caries progression, the default of the patient at the second appointment and additional costs and discomfort to the patient.

Recently, the real need to re-enter the cavity has been questioned in the literature (KIDD, 2004; RICKETTS et al., 2007), taking into account the evidences of caries arrestment after its isolation from the oral environment. Several studies have shown clinical, microhardness, radiographic and microbiological modifications at the carious dentine after its sealing: (a) clinical signs of darkening and hardening (BJØRNDAL; THYLSTRUP, 1998; BJØRNDAL; LARSEN; THYLSTRUP, 1997; MALTZ et al., 2002; PINTO et al., 2006), which was confirmed by microhardness measurements (MARCHI et al., 2008; FRANZON et al., 2009); (b) radiographic increase of the mineral content (MALTZ et al., 2002; MALTZ et al., 2007; OLIVEIRA et al., 2006) and (c) substantial reduction of bacterial contamination due to the lack of nutrition (BJØRNDAL; LARSEN; THYLSTRUP, 1997; MALTZ et al., 2002 WEERHEIJM et al., 1999; MASSARA; ALVES; BRANDÃO, 2002; PADDICK et al., 2005; WAMBIER et al., 2007). On a long-term basis, a 10-year follow-up study showed the control of caries process by sealants placed on caries lesions restricted to the outer half of dentine, recording a success rate of $86 \%$ (MERTZFAIRHURST et al., 1998). Based on all evidences described above, it has been suggested that the partial caries removal technique and the placement of the definitive restoration can be done at a single appointment, eliminating the possible complications of the stepwise excavation (KIDD, 2004; RICKETTS et al., 2007).

A series of publication derived from a single-arm clinical trial showed favorable results of the partial caries removal in deep lesions (MALTZ et al., 2002; MALTZ et al., 2007; OLIVEIRA et al., 2006; ALVES et al., 2010). After 10 years of monitoring, the success rate was $63 \%$ (ALVES et al., 2010). Despite the importance of this study due to its long-term follow-up period and low drop-out rate, the lack of a control group impedes the assessment of the effectiveness of this treatment, turning essential the development of randomized controlled clinical trials in this field.

The aim of the present study was to longitudinally assess patients with deep caries lesions submitted to partial caries removal after a period of 2 -year regarding tooth sensibility.

\section{Materials and Methods}

This multicenter randomized controlled clinical tria (registration number at www.clinicaltrials.gov NCT00887952) was conducted with patients submitted to a conservative approach to treat deep caries lesions in the permanent dentition. Clinical procedures were carried out in the Federal University of Rio Grande do Sul, Faculty of Sciences Health of the University of Brasília and Public Health Services. This study was approved by the Ethics Committees of Federal University of Rio Grande do Sul and University of Brasília. All patients were included in a preventive/therapeutic program. They or their legal guardians signed a free informed consent.

The initial sample consisted of 299 permanent posterior teeth with deep caries lesion from 232 patients (6 - 53 years of age) The inclusion criteria were: radiographic image of caries lesion in the inner half of dentine, positive response to the cold test with $-20^{\circ}$ refrigerated gas (Aerojet, Rio de Janeiro, RJ, Brazil), negative sensitivity to percussion test, no history of spontaneous pain radiographic absence of a periapical lesion and absence of cuspal loss.

The patients were randomly assigned by raffle to: (1) test group - partial caries removal and restoration in one appointment (PDR) and (2) control group - stepwise excavation (SW). The raffle was performed by an assistant during the clinical procedure. Each of the groups was divided according to the filling material, determined at weekly basis, alternating between amalgam and resin composite.

\section{Clinical procedures}

The patients were submitted to the following procedures: anesthesia and rubber dam isolation of the area to be treated; access to the affected area using rotator instruments, if necessary; complete removal of carious dentine from the surrounding cavity walls according to hardness criteria (rotator instruments and/or hand excavator); removal of the necrotic disorganized dentine from the cavity floor (hand excavator); washing of the cavity with distilled water; drying with sterile filter paper; group randomization. The tooth of the PCR received: partial filling of the cavity with glass ionomer cement (Vitro Fil, DFL, Rio de Janeiro, RJ, Brazil); restoration using amalgam (SDI, Bayswater WA, Australia) or resin composite (Tetric EvoCeram + Excite + Total Etch, Ivoclar/Vivadent, Liechtenstein). The tooth of the SE received: indirect pulp capping with calcium hydroxide cement (Dycal, Caulk/Dentsply, Rio de Janeiro, RJ, Brazil) and temporary filling with a modified zinc oxide-eugenol cement (IRM, Caulk/Dentsply, Rio de Janeiro, RJ, Brazil); cavity reopening after 60 days, followed by removal of the remaining decayed dentine and filling according to the same procedures described to PCR.

\section{Clinic and radiographic evaluation}

The treatment was evaluated after one and two years using the clinical and radiographic criteria. Pulp sensitivity was assessed by cold test and patients were asked about the occurrence of pain or sensitivity during percussion, assuming those parameters as indicators of pulp sensibility. Periapical and bitewing radiographs were taken to analyze the integrity of the periapical region and the area of carious dentine left under the restoration.

\section{Statistical data processing}

Chi-square test was used to compare the success rates of the two experimental groups.

Logistic regression analysis was used to investigate possible associations between dichotomous outcome variable (success vs. failure) and independent variables: treatment, number of restored surfaces, age and gender.

Chi-square test or Mann-Whitney test was used to compare patients followed-up after two years and patients lost to recall. significant.

A p-value lower than 0.05 was considered statistically

Statistical analyses were conducted using the Statistical Package for Social Science (SPSS) software, version 13.0, for Windows.

\section{Results}

There were performed 299 treatments, 153 PDR and 146 $\mathrm{SW}$. There were no differences between the groups regarding baseline characteristics: age, gender and family income ( $p>0.05)$.

Table 1. Subjects baseline characteristics according to the proportion of the evaluated patients and those lost to recall.

\begin{tabular}{lc}
\hline Variable & $\mathrm{p}$ \\
\hline Gender & 0.638 \\
Age & 0.029 \\
Family income & 0.146 \\
Treatment & 0.015 \\
Restorative material & 0.245 \\
Number of restored surfaces & 0.068 \\
\hline
\end{tabular}


A total of 23 therapeutic failures were observed, 5 in the PCR and 18 in the control group. Reasons for failure were pulpitis, osteitis, hyperemia, necrosis, extraction and restoration fracture. There is no information regarding the reason for the extraction in the SE.

The number of teeth evaluated after one and two years were 213 and 204, been the cumulative drop-out rate of $31.77 \%$. There were no differences between the evaluated patients and those lost to recall regarding family income, gender, restorative material and number of restored surface. However, differences were found regarding age and treatment (Table 1).

After 2 years of follow-up, therapy success rates of PDR and SW were $95.45 \%$ and $80.85 \%$, respectively $(p=0.001)$ (Table 2 ). The number of failures in the SW group was 14 in the first year, increasing to 18 at the second year. In the PDR, 5 failures were recorded at the first year and continue the same in the second year.

Table 2. Success rates (outcome: pulp vitality) after 24 months of follow up according to the different groups.

\begin{tabular}{lcccc}
\hline & $\begin{array}{c}\text { Success } \\
\mathrm{N}(\%)\end{array}$ & $\begin{array}{c}\text { Failure } \\
\mathrm{N}(\%)\end{array}$ & $\begin{array}{c}\text { Total } \\
\mathrm{N}\end{array}$ & $\mathrm{p}$-value \\
\hline PDR & $105(95.45)$ & $05(4.54)$ & 110 & \\
SW & $76(80.85)$ & $18(19.15)$ & 94 & $\mathrm{p}^{*}=0.001$ \\
Total & $181(88.72)$ & $23(11.27)$ & 204 & \\
\hline
\end{tabular}

$\mathrm{PDR}=$ Partial dentine removal; SE=Stepwise excavation; * Chisquare test

At the logistic regression analysis, there was none significant association among the variables age, gender, family income, restorative material, number of restored surfaces, and a significant association with treatment and the outcome (Table 3).

Table 3. Logistic regression analysis final model considering pulp sensitivity as the dependent variable. Age and family income were treated as continuous variables. All the other variables were categorical.

\begin{tabular}{lcc} 
Variable & $\mathrm{p}$ & $\begin{array}{c}95 \% \mathrm{Cl} \\
\text { Lower }\end{array}$ \\
\hline Treatment & 0.001 & 0.056 \\
Filling material & 0.355 & 0.573 \\
Age & 0.630 & 0.952 \\
Gender & 0.617 & 0.273 \\
Number of surfaces & 0.210 & 0.673 \\
Size of the cavity & 0.201 & 0.179 \\
Family income & 0.706 & 1.000 \\
\hline
\end{tabular}

\section{Discussion}

PDR in deep caries lesions presented a higher success rate than the SW after two years.

The SW is the therapy presenting a longer maintenance of pulp vitality and tooth structure compared to complete caries removal. The complete caries removal leads to a higher rate of pulp exposure, which has worse pulp prognosis (BARTHEL et al., 2000). The present study shows that the PDR in one session present a higher success rate than SW.

In the SW treatment, the failure of the temporary restoration may lead to caries progression and endodontic complications after a certain period of time (Bjørndal et al., 2010; Bjørndal and Thylstrup, 1998; Leksell et al., 1996; Magnusson and Sundell, 1977). The dependence of patients' return to conclude the stepwise excavation, coupled with the lack of evidence of the need of cavity reopening for final excavation suggest that the treatment in a single appointment may be preferable. Longitudinal clinical studies require patient collaboration to attending follow-up appointments. Of the 232 patients treated, 213 returned after one year and 204 after two years of the initial treatment. In order to assess the possible inclusion of a bias, patients who attended the 2year follow-up were compared with those lost to recall. The two variables which were significantly different from one another were age and treatment. The age does not seem to compromise our results, once it has no association with pulp prognosis regarding pulp conservative therapies (BJØRNDAL; THYLSTRUP, 1998; ALHIYASAT; BARRIESHI-NUSAIR; AL-OMARI, 2006 DAMMASCHKE; LEIDINGER; SCHAFER, 2009). Regarding treatment, the stepwise excavation presented worse success rate, once this group presented the higher drop-out rate, not returning to complete the treatment. The maintenance of the temporary filling may lead to several negative results: fracture/loss of the temporary filling, fracture of the tooth structure, caries progression and, finally, irreversible damage to the pulp (Bjørndal et al., 2010; Bjørndal and Thylstrup, 1998; Leksell et al., 1996; Magnusson and Sundell, 1977).

In conclusion, based on our findings, it is possible to state that the partial caries removal is a more successful therapy than stepwise excavation after two years. This result corroborate previous studies suggesting that it is unnecessary to completely remove carious dentine prior to a restoration in order to maintain pulp sensibility (MALTZ et al., 2002; KIDD, 2004; OLIVEIRA et al., 2006; RICKETTS et al., 2007; MALTZ et al., 2007; ALVES et al., 2010).

\section{Acknowledgments}

We thank the support of National Coordination of Postgraduate Education (CAPES), Brazilian Ministry of Science and Technology through its agency National Council of Research (CNPq - Process number: 40.3420/04-0), Research Support Fund of Rio Grande do Sul (FAPERGS - Process number: 04/1531-8) and the support of industries DFL (Rio de Janeiro, Brazil), Ivoclar/Vivadent (Schaan, Liechtenstein) and SDI (Bayswater WA, Australia).

\section{References}

AL-HIYASAT, A. S.; BARRIESHI-NUSAIR, K. M.; AL-OMARI, M. A. The radiographic outcomes of direct pulp-capping procedures performed by dental students: a retrospective study. J. Am. Dent. Assoc., Chicago, v. 137, n. 12, p. 1699-1705, Dec. 2006.

ALVES, L. S.; FONTANELLA, V.; DAMO, A. C.; FERREIRA DE OLIVEIRA, E.; MALTZ, M. Qualitative and quantitative radiographic assessment of sealed carious dentin: a 10-year prospective study. Oral Surg. Oral Med. Oral Pathol. Oral Radiol. Endod., St. Louis, v. 109, n. 1, p. 135-141, Jan. 2010.

BARTHEL, C. R.; ROSENKRANZ, B.; LEUENBERG, A.; ROULET, J. F. Pulp capping of carious exposures: treatment outcome after 5 and 10 years: a retrospective study. J. Endod., Chicago, v. 26, n. 9, p. 525-528, Sep. 2000.

BJØRNDAL, L.; LARSEN, T.; THYLSTRUP, A. A clinical and microbiological study of deep carious lesions during stepwise excavation using long treatment intervals. Caries Res., Basel, v. 31, n. 6, p. 411-417, Nov./Dec. 1997.

BJØRNDAL, L.; THYLSTRUP, A. A practice-based study on stepwise excavation of deep carious lesions in permanent teeth: a 1-year follow-up study. Community Dent. Oral Epidemiol. Copenhagen, v. 26, n. 2, p. 122-128, Apr. 1998.

DAMMASCHKE, T.; LEIDINGER, J.; SCHAFER, E. Long-term evaluation of direct pulp capping-treatment outcomes over an average period of 6.1 years. Clin. Oral Investig., Berlin, v.14, n. 5, p. 559-567, Aug. 2009. 
FRANZON, R.; PITONI, C. M.; GOMES, M.; BERGMANN, C. P.; de ARAÚJO, F. B. Dentin rehardening after indirect pulp treatment in primary teeth. J. Dent. Child., Chicago, v. 76, n. 3, p. 223-228, Sep./Dec. 2009.

KIDD, E. A. M. How 'clean' must a cavity be before restoration? Caries Res., Basel, v. 38, n. 3, p. 305-313, May/Jun. 2004.

KING, J. B.; CRAWFORD, J. J.; LINDAHL, R. L. Indirect pulp capping: a bacteriologic study of deep carious dentin in human teeth. Oral Surg. Oral Med. Oral Pathol., St. Louis, v. 20, n. 5, p. 663-669, Nov. 1965.

LEKSELL, E.; RIDELL, K.; CVEK, M. E.; MEJARE, I. Pulp exposure after stepwise versus direct complete excavation of deep carious lesions in young posterior permanent

teeth. Endod. Dent. Traumatol., Copenhagen, v. 12, n. 4, p. 192 196, Aug. 1996

MAGNUSSON, B. O.; SUNDELL, S. O. Stepwise excavation of deep carious lesions in primary molars. J. Int. Assoc. Dent. Child., London, v. 8, n. 2, p. 36-40, Dec. 1977.

MALTZ, M.; OLIVEIRA, E. F.; FONTANELLA, V.; BIANCHI, R. A clinical, microbiologic, and radiographic study of deep lesions, after incomplete caries removal. Quintessence Int., Berlin, v. 33, n. 2, p. 151-159, Feb. 2002.

MALTZ, M.; OLIVEIRA, E. F.; FONTANELLA, V.; CARMINATTI, G. Deep caries lesions after incomplete dentine caries removal: 40 month follow-up study. Caries Res., Basel, v. 41, n. 6, p. 493-496, Nov. 2007.

MARCHI, J. J.; FRONER, A. M.; de ARAÚJO, F. B.; ALVES, H. L. R.; BERGMANN, C. P. Analysis of primary tooth dentin after indirect pulp capping. J. Dent. Child., Chicago, v. 75, n. 3, p. 160-165, Sep./Dec. 2008

MASSARA, M. L. A.; ALVES, J. B.; BRANDÃO, P. R. G. Atraumatic restorative treatment: clinical, ultrastructural and chemical analysis. Caries Res., Basel, v. 36, n. 6, p. 430-436, Nov./Dec. 2002.

MASSLER, M. Treatment of profound caries to prevent pulpa damage. J. Pedod., Birmingham, v. 2, n. 2, p. 99-105, Winter 1978.

MERTZ-FAIRHURST, E. J.; CURTIS Jr., J. W.; ERGLE, J. W.; RUEGGEBERG, F. A.; ADAIR, S. M. Ultraconservative and cariostatic sealed restorations: Results at year 10. J. Am. Dent. Assoc., Chicago, v. 129, n. 1, p. 55-66, Jan. 1998.

OLIVEIRA, E. F.; CARMINATTI, G.; FONTANELLA, V.; MALTZ M. The monitoring of deep caries lesions after incomplete caries removal: results after 14-18 months. Clin. Oral Investig., Berlin, v. 10, n. 2, p. 134-139, Jun. 2006

PADDICK, J. S.; BRAILSFORD, S. R.; KIDD E. A. M.; BEIGHTON, D. Phenotypic

and genotypic selection of microbiota surviving under dental restorations. Appl. Environ. Microbiol., Washington, v. 71, n. 5, p. 2467-2472, May 2005

PINTO, A. S.; de ARAÚJO, F. B.; FRANZON, R.; FIGUEIREDO, M C.; HENZ, S.; GARCÍA-GODOY, F.; MALTZ, M. Clinical and microbiological effect of calcium hydroxide protection in indirect pulp capping in primary teeth. Am. J. Dent., San Antonio, v. 19, n. 6, p. 382-386, Dec. 2006.
RICKETTS, D.; KIDD, E. A.; INNES, N. P. T.; CLARKSON, J. E. Complete or ultraconservative removal of decayed tissue in unfilled teeth. Aust. Dent. J., Sydney, v. 52, n. 3, p. 252-253, Sep. 2007.

WAMBIER, D. S.; dos SANTOS, F. A.; GUEDES-PINTO, A. C.; JAEGER, R. G.; SIMIONATO, M. R. Ultrastructural and microbiological analysis of the dentin layers affected by caries lesions in primary molars treated by minimal intervention. Pediatric. Dent., Chicago, v. 29, n. 3, p. 228-234, May/Jun. 2007.

WEERHEIJM, K. L.; KREULEN, C. M.; DE SOET, J. J.; GROEN, H. J.; VAN AMERONGEN, W. E. Bacterial counts in carious dentine under restorations: 2-year in vivo effects. Caries Res., Basel, v. 33, n. 2, p. 130-134, Mar./Apr. 1999. 